UDK $577.1: 61$

ISSN 1452-8258

J Med Biochem 37: 397-405, 2018

Original paper

Originalni naučni rad

\title{
EXTERNAL QUALITY ASSESSMENT OF GLYCATED HEMOGLOBIN IN IRAN: COMPARISON OF FIVE DIFFERENT COMMERCIAL METHODS WITH TWO DIFFERENT TOTAL ALLOWABLE ERRORS
}

\author{
EKSTERNA PROCENA KVALITETA GLIKOLIZIRANOG HEMOGLOBINA U IRANU: \\ POREĐENJE PET RAZLICITIH KOMERCIJALNIH METODA SA \\ DVE RAZLIČITE UKUPNE DOZVOLJENE GREŠKE
}

\author{
Fereshteh Atabi ${ }^{1}$, Reza Mohammadi ${ }^{1,2}$ \\ ${ }^{1}$ Department of Biochemistry and Pharmacology, Islamic Azad University, \\ Tehran Medical Sciences Branch, Tehran, Iran \\ ${ }^{2}$ Department of Biochemistry of External Quality Assessment Program, \\ Iranian Association of Clinical Laboratory Doctors, Tehran, Iran
}

\begin{abstract}
Summary
Background: Glycated hemoglobin $\left(\mathrm{HbA}_{1 \mathrm{c}}\right)$ measuring has a critical role in the monitoring and diagnosis of diabetes. So, the analytical performance of its measuring method must be acceptable. Clinical laboratories should continuously monitor the performance of their commercial methods, both by using proper internal quality control (IQC) and by participating in external quality assessment schemes (EQAS).

Methods: In January and August 2016, two different freshly prepared commutable patient QC samples were sent to over 1000 laboratories, but 682 and 925 different laboratories which were used five common commercial methods for measuring $\mathrm{HbA}_{1 \mathrm{c}}$ included in this study during $23^{\text {th }}$ and $24^{\text {th }}$ runs of the external quality assessment program (EQAP), respectively. Target values for total group and also for peer groups were calculated. The performance of each method and laboratory were determined according to two different allowable total errors (TEa), including $\pm 6 \%$ and $\pm 20 \%$, which are suggested by the National Glycohemoglobin Standardization Program (NGSP) and Reference Health Laboratory of Iran, respectively.

Results: Considering TEa of $\pm 20 \%$ in evaluating $\mathrm{HbA}_{1 \mathrm{c}}$ commercial methods and laboratory performances, pass
\end{abstract}

\begin{abstract}
Kratak sadržaj
Uvod: Merenje glikoliziranog hemoglobina $\left(\mathrm{HbA}_{1 c}\right)$ ima presudnu ulogu u praćenju i dijagnostikovanju dijabetesa. Zbog toga, metode za njegovo merenje moraju imati prihvatljive analitičke performanse. Kliničke laboratorije moraju stalno da prate performanse svojih komercijalnih metoda, kako korišćenjem odgovarajuće interne kontrole kvaliteta (IQC) tako i kroz učešće u šemama spoljne procene kvaliteta (EQAS).

Metode: Tokom 23. i 24. kruga programa spoljne procene kvaliteta (EQAP), u januaru i avgustu 2016, dva različita sveže pripremljena komutabilna QC uzorka pacijenata poslata su u 682 i 925 različitih laboratorija koje koriste pet uobičajenih komercijalnih metoda za merenje $\mathrm{HbA}_{1 c}$. Izračunate su ciljne vrednosti za ukupnu grupu i srodne grupe (peer groups).

Rezultati: Performanse svake metode i laboratorije određene su u odnosu na dve različite dozvoljene ukupne greške (TEa), naime $\pm 6 \%$ i $\pm 20 \%$, predložene od strane Nacionalnog programa za standardizaciju glikohemoglobina (NGSP) i Referentne zdravstvene laboratorije Irana. Kad se radi od TEa od $\pm 20 \%$ u evaluaciji komercijalnih metoda za $\mathrm{HbA}_{1 \mathrm{c}}$ i laboratorijskih performansi, stope prolaznosti (pass rates) bile su od $97 \%$ do $98 \%$ tokom EQAP-23 i EQAP-24. Međutim, kada
\end{abstract}

\footnotetext{
Address for correspondence:

Dr. Reza Mohammadi

Department of Biochemistry and Pharmacology, Islamic Azad

University, Tehran Medical Sciences Branch, Tehran, Iran

Department of Biochemistry of External Quality Assessment Program,

Iranian Association of Clinical Laboratory Doctors, Tehran, Iran

e-mail: rmohamadi@iautmu.ac.ir.

Fax: +98 (21) 22618550.

Tel: $+98(21) 22006660-(374)$

Mob: +98912615 5063
} 
rates ranged from $97 \%$ to $98 \%$ during EQAP-23 and EQAP-24, respectively. But when this evaluation was performed according to TEa of $\pm 6 \%$, pass rates decreased significantly to $60 \%$ and $62 \%$, respectively.

Conclusions: Using improper analytical goals has led to misinterpretation of EQA results. In order to maintain the clinical usefulness of $\mathrm{HbA}_{1}$ results, we need to reduce TEa of $\pm 20 \%$ to $\pm 6 \%$ and improve $\mathrm{HbA}_{1 \mathrm{c}}$ measuring method performance. Although, with TEa of $\pm 6 \%$ our pass rates are not so bad.

Keywords: analytical goals, EQA, glycated hemoglobin, $\mathrm{HbA}_{1 \mathrm{c}}$

\section{Introduction}

According to the critical role of the level of glycated hemoglobin $\left(\mathrm{HbA}_{1 \mathrm{c}}\right)$ in the monitoring and diagnosis of diabetes $(1,2)$ the acceptable precision and accuracy of different commercial methods in clinical laboratories for measuring $\mathrm{HbA}_{1 \mathrm{c}}$ is essential (3). There are many different methods such as ionexchange chromatography, capillary electrophoresis, boronate affinity chromatography, immunoassay and enzymatic methods, which separate glycated hemoglobins from nonglycated ones, based on existing differences in structure, charge, affinity or immunity (2).

The manufacturers should produce commercial methods that their results could be traceable to the higher-order references and be able to achieve acceptable analytical goals of measurement (3). Analytical goals must be defined in such a way that the test could save its clinical usefulness. On the other hand, it is the responsibility of clinical laboratories to monitor the performance of their methods, both by using a proper internal quality control (IQC) and participating in external quality assessment schemes (EQAS) (3). In addition, before routinely using any commercial methods for analyzing patient specimens, each laboratory should verify method producer claims or validate method performance according to the laboratory analytical goals (4). In each above experiment, including IQC, EQAS, and method validation, judgement of method performance acceptability depends on the established allowable total error (TEa). TEa is a maximum tolerable error that, if it occurs, will not impair the result's clinical usefulness (5-7).

In order to significantly reduce differences between results obtained by various commercial methods, standardization of the methods of $\mathrm{HbA}_{1 \mathrm{c}}$ measurement has been necessary. This can be achieved by the International Federation of Clinical Chemistry (IFCC) and National Glycohemoglobin Standardization Program (NGSP) (5). The American Diabetes Association (ADA) recommends that laboratories use only NGSP-certified $\mathrm{HbA}_{1 \mathrm{c}}$ methods and participate in the College of American Pathologists (CAP) fresh sample proficiency testing survey $(6,7)$. Using NGSP certified methods is not the only step in achieving a precise and accurate analytical $\mathrm{HbA}_{1 \mathrm{c}}$ measuring je evaluacija izvršena prema TEa od $\pm 6 \%$, ove stope su se značajno smanjile na $60 \%$, odnosno $62 \%$.

Zaključak: Korišćenje neodgovarajućih analitičkih ciljeva dovelo je do pogrešne interpretacije rezultata EQA. Kako bi se održala klinička korisnost rezultata $\mathrm{HbA}_{1 \mathrm{c}}$, potrebno je da snizimo TEa sa $\pm 20 \%$ na $\pm 6 \%$ i popravimo performanse metoda za merenje $\mathrm{HbA}_{1 c}$. Mada, uz TEa od $\pm 6 \%$, naše stope prolaznosti i nisu bile tako loše.

Ključne reči: analitički ciljevi, EQA, glikolizirani hemoglobin, $\mathrm{HbA}_{1 \mathrm{c}}$

method. Continuous monitoring of the performance of the method is needed. In this regard, defining analytical goals with which method performance must be evaluated, has profound effects on detection of analytical errors.

The exact number of errors made can be quantified by employing sigma metrics in the laboratory. According to selected TEa along with method bias and imprecision, we can calculate sigma of the method which is a valuable criterion for assessing the quality of the analytical phase. A high sigma value indicates good performance. A sigma value of 2 is defined as the minimum allowable value for routine performance (8).

Unfortunately, there are few reports about the performance of clinical laboratories measuring $\mathrm{HbA}_{1 c}$ in EQAS and proficiency testing (PT) of different countries. In the United States, CAP publishes these data regularly and some reports can be found from some other countries, including Italy and China. In this study, for the first time in Iran, we evaluated the effects of two different analytical goals, defined as $\mathrm{TEa}$, on interpretation of EQAS $\mathrm{HbA}_{1 \mathrm{c}}$ results. TEa encompasses the imprecision and bias of a single test measurement and is used to evaluate laboratory tests performance in EQAS (9). We also evaluated the analytical performance of the methods by calculating the sigma value of each method according to different TEa.

\section{Materials and Methods}

\section{Sample Preparation}

Pooled whole bloods were collected from diabetic patients who suffered from polycythemia and should have regular phlebotomy to reduce their red blood cell count. The bloods were collected in EDTA containing bags and then four or five isogroup bloods were mixed in order to have enough blood (about $1500 \mathrm{~mL}$ ) for filling each $\mathrm{HbA}_{1 \mathrm{c}}$ vial with $1.0 \mathrm{~mL}$ pooled whole blood. In this preparation, only EDTA, with no preservatives was added as a coagulant which is recommended by method producer. So in comparison to routine blood collection for $\mathrm{HbA}_{1 \mathrm{c}}$ measuring, 
the matrix of the blood was not changed and we can consider them commutable.

\section{Explanation of the Procedure}

During twenty third and twenty fourth runs of the external quality assessment program (EQAP-23 and EQAP-24), in January 2016 and August 2016, two different freshly prepared commutable patient whole blood samples in EDTA-containing vials were sent to 966 and 1393 participant laboratories, respectively, at $4{ }^{\circ} \mathrm{C}$ to $8{ }^{\circ} \mathrm{C}$. In order to protect the blood samples against possible degradation and leakage during mailing, the plastic tubes were filled with the whole blood and sealed with stoppers and inserted into a triple container. The first container is a cold box with adequate ice bag for cooling the filled tubes. The second one is the Styrofoam container which acts as a thermal insulation and a water barrier and the last one is a carton on which the names and the addresses of the providers and participants together with the information about the mailing cautions have been recorded.

Using commutable samples, the results of different commercial methods can be compared (10). Before sending to participating laboratories, homogeneity of whole blood vials and after sending, the stability of these vials was assessed and confirmed. These assessments and confirmation were done according to WHO requirements (11). For homogeneity, about one percent of total vials, including ten and fourteen vials were randomly selected during EQAP-23 and EQAP-24, respectively, and their $\mathrm{HbA}_{1 \mathrm{c}}$ determined by Tosoh G8 Auto HPLC in duplicate. Then the coefficient of variation (CV) of the results was calculated and compared with one fourth of an allowable total error of $6 \%$, or $1.5 \%$. For stability, one whole blood vial in each run was refrigerated by the end of the program and then the $\mathrm{HbA}_{1 c}$ was measured in duplicate and the average of the results compared with the homogeneity mean value \pm modified allowable total error (mTEa\%).

Although there are more than ten commercial methods for monitoring of $\mathrm{HbA}_{1 \mathrm{c}}$ in Iran. This study was focused on common methods for which the number of using laboratories was at least twenty. So their statistical analysis could be valid, and their performance had also been evaluated (12). These included Biosystem, Nycocard, Pars Azmon, Pishtaz Teb, and Roche kits which their assay principles were cationexchange chromatography, boronate-affinity chromatography, immunoturbidimetry, enzymatic, and immunoturbidimetry, respectively.

In EQAP-23, 682 participating laboratories used the desired commercial methods. These laboratories were grouped in five peer groups, including Biosystem, NycoCard, Pars Azmon, Pishtaz Teb, and Roche with 172, 233, 120, 137, and 20 participating laboratories, respectively. In EQAP-24, 925 participating laboratories used the desired commercial methods. These laboratories were grouped in five peer groups, including Biosystem, NycoCard, Pars Azmon, Pishtaz Teb, and Roche with 209, 337, 149, 205, and 25 participating laboratories, respectively. Each participant laboratory had to examine the sent control material as a routine patient sample according to the instructions of commercial method manufacturers and had to calibrate and control its measuring method by the calibrators and control materials, as an internal quality control, provided by method manufacturers. After measuring $\mathrm{HbA}_{1 \mathrm{c}}$, the results were sent to EQAP and statistical analyses were done. According to the used commercial method, the results were grouped into five peer groups. Then, mean, SD, and CV of each peer group and also total results were calculated. In EQA, the mean of each peer group is used as target value to evaluate each laboratory performance. In this regard, it is necessary to delete outliers which are out of Mean \pm 2 SD or $3 S D$ (13). In EQAP, Mean $\pm 2.5 S D$ is used. After deleting outliers, calculation of mean and SD was repeated until there were no outliers. The last calculated mean, termed as weighted mean, was used as the target value. Statistical analysis was done by SPSS 20 and Med Calc 13.3.1 software.

Target values for total group and also for peer groups were calculated. In Iran, laboratory performance is evaluated according to standard deviation interval (SDI). SDI is commonly calculated by the following formula (6-14):

$\mathrm{SDI}=\frac{\text { Laboratory result }- \text { Peer group target value }}{\text { Peer group SD }}$

but adjusted SD instead of peer group SD is used. Adjusted SD is calculated by the following formula:

Adjusted SD $=\frac{\text { CCV\% } \times \text { Peer group target value }}{100}$

in which, CCV (Chosen Coefficient of Variation) is defined by the Reference Health Laboratory of Iran and equals $10 \%$ for $\mathrm{HbA}_{1 \mathrm{c}}$ methods. SDI $\leq 2$ is considered as acceptable result (12). This CCV and acceptability criteria represent TEa of $20 \%$; i.e. SDI = 2 shows that the result is 2 SD far from mean target value and SD equals $10 \%$ of mean target value, so TEa $=2 \mathrm{SD}=2 \times 10 \%=20 \%$.

For calculating the relative bias of the mean value of each commercial method, in comparison to the mean value of all groups, we subtracted peer group mean value from the all groups mean value. According to NGSP, bias up to $0.3 \%$ of absolute $\mathrm{HbA}_{1 \mathrm{c}}$ was considered acceptable. 
Total analytical error (TAE) has two parts, including bias and imprecision which are representative of systematic and random errors, respectively. For calculating bias\% of each commercial method, first the TAE\% of each method is calculated by the following formula:

$\mathrm{TAE} \%=\frac{\text { (peer group mean value) }- \text { (all groups mean value) }}{\text { all groups mean value }} \times 100$.

TAE\% is commonly calculated as bias $\%+2$ CV\% $(15,16)$. The components of analytical errors of a single measurement result include random and systematic errors. In comparison with a single measurement, when two or more replicate measurements are made, the mean of the obtained values is more likely to be closer to the true or target value, since repeated measurements decrease the effect of the random error of the mean. Ultimately, when an infinite number of measurements are made, the effect of random error on the mean will be eliminated (16). The effect of a random error component of TAE is inversely related to the square root of the number of measurements $(16,17)$. If a test is repeated, its random error will decrease by $1 / \sqrt{n}$, in which $n$ is the number of repeats (17). Thus, according to the number of measurement repeats, the effects of random error (imprecision) and systematic error (bias) on TAE can be calculated. In calculating bias\%, we used the following formula to eliminate the effect of random error on TAE according to the number $(n)$ of participant laboratories in each peer group:

$$
\text { Bias } \% \text { TAE } \%=\frac{\sqrt{n}}{2+\sqrt{n}} \times \text { TAE } \%
$$

We can define modified total analytical error ( $m T E a$ ) for when the test is repeated $n$ times. In this way, we can determine TEa for situations when the test is repeated, for example 2, 4, 10 or 20 times.

$$
\mathrm{mTEa} \%=\frac{2+\sqrt{n}}{3 \times \sqrt{n}} \times \mathrm{TEa} \%
$$

this formula was derived from $\mathrm{mTEa} \%=\mathrm{Bias} \%+2 \mathrm{CV} \% / \sqrt{n}$ when test is repeated $n$ times.

Also, we calculated pass rates of laboratories having acceptable results during EQAP-23 and EQAP-24 with TEa of $\pm 20 \%$ suggested by the Reference Health Laboratory of Iran and TEa of $\pm 6 \%$ suggested by NGSP and CAP $(5,18)$. In this comparison, we used total mean as target value.

Commercial methods quality, as the sigma value of each method performance, was calculated according to the above two different TEa along with Bias and CV of each method (9):

$$
\text { Method quality (sigma) }=\frac{\mathrm{TEa} \%+\mathrm{Bias} \%}{\mathrm{CV} \%}
$$

\section{Results}

In EQAP-23, and EQAP-24, the CVs of homogeneity studies were $0.8 \%$ and $0.9 \%$ respectively,

\begin{tabular}{|c|c|c|c|c|c|c|c|c|}
\hline \multirow{2}{*}{$\begin{array}{l}\text { Commercial } \\
\text { Methods }\end{array}$} & \multirow{2}{*}{$\begin{array}{l}\text { No. } \\
\text { labs }\end{array}$} & \multirow{2}{*}{$\begin{array}{c}\text { Mean } \\
(\%)\end{array}$} & \multirow{2}{*}{ SD } & \multirow{2}{*}{$\begin{array}{l}\text { CV } \\
(\%)\end{array}$} & \multirow{2}{*}{$\begin{array}{l}\text { TAE } \\
(\%)\end{array}$} & \multirow{2}{*}{$\begin{array}{l}\text { Bias } \\
(\%)\end{array}$} & \multicolumn{2}{|c|}{ Method quality (sigma) } \\
\hline & & & & & & & $\mathrm{TEa}=6 \%$ & $\mathrm{TEa}=20 \%$ \\
\hline \multicolumn{9}{|l|}{ EQAP-23 } \\
\hline Biosystem & 172 & 7.93 & 0.83 & 10.5 & -0.50 & -0.44 & 0.61 & 1.95 \\
\hline NycoCard & 233 & 8.05 & 0.52 & 6.5 & +1.00 & +0.89 & 0.79 & 2.96 \\
\hline Pasr Azmon & 120 & 7.99 & 0.73 & 9.1 & +0.25 & +0.21 & 0.63 & 2.17 \\
\hline Pishtaz Teb & 137 & 7.78 & 0.59 & 7.6 & -2.38 & -2.04 & 1.06 & 2.91 \\
\hline Roche & 20 & 8.12 & 0.32 & 3.9 & +1.88 & +1.30 & 1.19 & 4.75 \\
\hline Total & 682 & 7.97 & 0.62 & 7.8 & - & - & - & - \\
\hline \multicolumn{9}{|l|}{ EQAP-24 } \\
\hline Biosystem & 209 & 7.66 & 0.90 & 11.8 & +0.13 & +0.11 & 0.50 & 1.69 \\
\hline NycoCard & 337 & 7.63 & 0.53 & 7.0 & -0.26 & -0.24 & 0.90 & 2.91 \\
\hline Pasr Azmon & 149 & 7.70 & 0.61 & 7.9 & +0.65 & +0.56 & 0.69 & 2.45 \\
\hline Pishtaz Teb & 205 & 7.60 & 0.57 & 7.5 & -0.65 & -0.57 & 0.88 & 2.74 \\
\hline Roche & 25 & 7.88 & 0.39 & 5.0 & +3.01 & +2.15 & 0.78 & 3.61 \\
\hline Total & 925 & 7.65 & 0.62 & 8.1 & - & - & - & - \\
\hline
\end{tabular}

Table I Weighted mean (target value), SD, CV, TAE, Bias\%, and method quality according to two different TEa in EQAP-23 and EQAP-24.

Abbreviations: TAE, total analytical error; TEa, allowable total error; $\mathrm{HbA}_{1 c}$, glycated hemoglobin; EQAP-23, twenty-third run of external quality assessment program; EQAP-24, twenty-fourth run of external quality assessment program. 
Table II Acceptable range and pass rates of $\mathrm{HbA}_{1 \mathrm{c}}$ in EQAP-23 and EQAP-24 with different allowable total error (TEa).

\begin{tabular}{|c|c|c|c|c|c|c|c|c|}
\hline \multirow{3}{*}{$\begin{array}{l}\text { Commercial } \\
\text { Methods }\end{array}$} & \multirow{3}{*}{$\begin{array}{l}\text { No. } \\
\text { Labs }\end{array}$} & \multirow{3}{*}{$\begin{array}{c}\text { Reported } \\
\text { Range (\%) }\end{array}$} & \multicolumn{3}{|c|}{$\mathrm{TEa}=6 \%$} & \multicolumn{3}{|c|}{$\mathrm{TEa}=20 \%$} \\
\hline & & & \multirow{2}{*}{$\begin{array}{c}\text { Acceptable } \\
\text { range } \\
(\%)\end{array}$} & \multicolumn{2}{|c|}{ Pass Rates } & \multirow{2}{*}{$\begin{array}{c}\text { Acceptable } \\
\text { range } \\
(\%)\end{array}$} & \multicolumn{2}{|c|}{ Pass Rates } \\
\hline & & & & $\mathrm{N}$ & $\%$ & & $\mathrm{~N}$ & $\%$ \\
\hline \multicolumn{9}{|l|}{ EQAP-23 } \\
\hline Biosystem & 172 & 5.90-10.00 & \multirow{6}{*}{ 7.49-8.45 } & 86 & 50 & \multirow{6}{*}{$6.38-9.56$} & 159 & 92 \\
\hline NycoCard & 233 & $6.80-9.20$ & & 163 & 70 & & 233 & 100 \\
\hline Pasr Azmon & 120 & $6.20-9.80$ & & 62 & 52 & & 115 & 96 \\
\hline Pishtaz Teb & 137 & $6.40-9.10$ & & 92 & 67 & & 137 & 100 \\
\hline Roche & 20 & $7.69-8.69$ & & 17 & 85 & & 20 & 100 \\
\hline Total & 682 & 5.90-10.0 & & 420 & 62 & & 664 & 97 \\
\hline \multicolumn{9}{|l|}{ EQAP-24 } \\
\hline Biosystem & 209 & $5.56-9.80$ & \multirow{6}{*}{$7.19-8.11$} & 96 & 46 & \multirow{6}{*}{$6.12-9.18$} & 189 & 90 \\
\hline NycoCard & 337 & $6.40-8.90$ & & 224 & 66 & & 337 & 100 \\
\hline Pasr Azmon & 149 & $6.20-9.10$ & & 86 & 58 & & 149 & 100 \\
\hline Pishtaz Teb & 205 & $6.20-9.00$ & & 132 & 64 & & 205 & 100 \\
\hline Roche & 25 & $7.01-8.45$ & & 17 & 68 & & 25 & 100 \\
\hline Total & 925 & $5.56-9.80$ & & 555 & 60 & & 905 & \\
\hline
\end{tabular}

Abbreviations: $\mathrm{HbA}_{1 c}$, glycated hemoglobin; EQAP-23, twenty-third run of external quality assessment program; EQAP-24, twenty-fourth run of external quality assessment program.

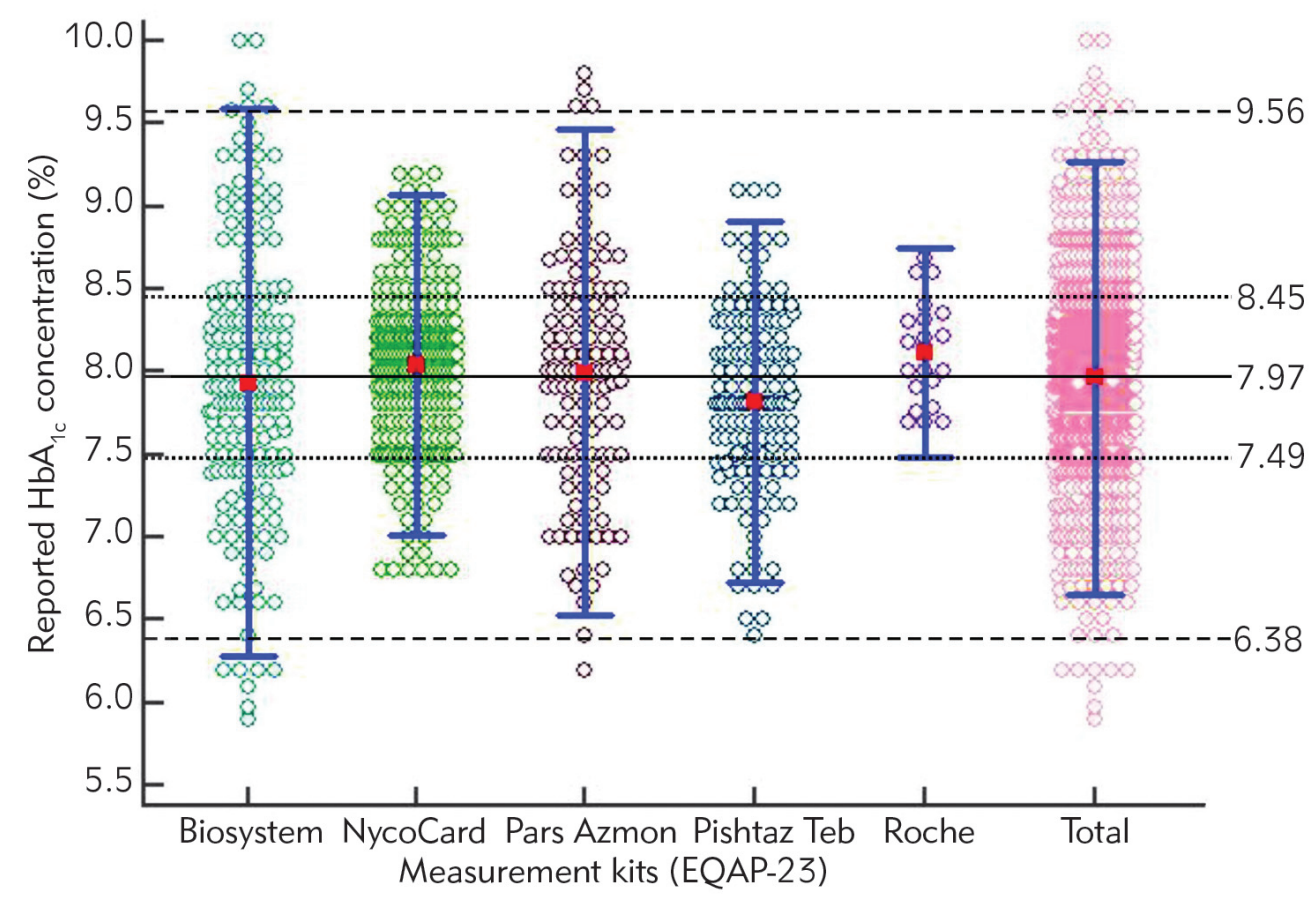

Figure 1 Performance during EQAP-23. Error bars represent $\pm 2 S D$ interval from the means (filled squares). The continuous horizontal line represents the total mean. Dotted and dashed horizontal lines show the allowable interval for total allowable errors of $6 \%$ and 20 , respectively. 


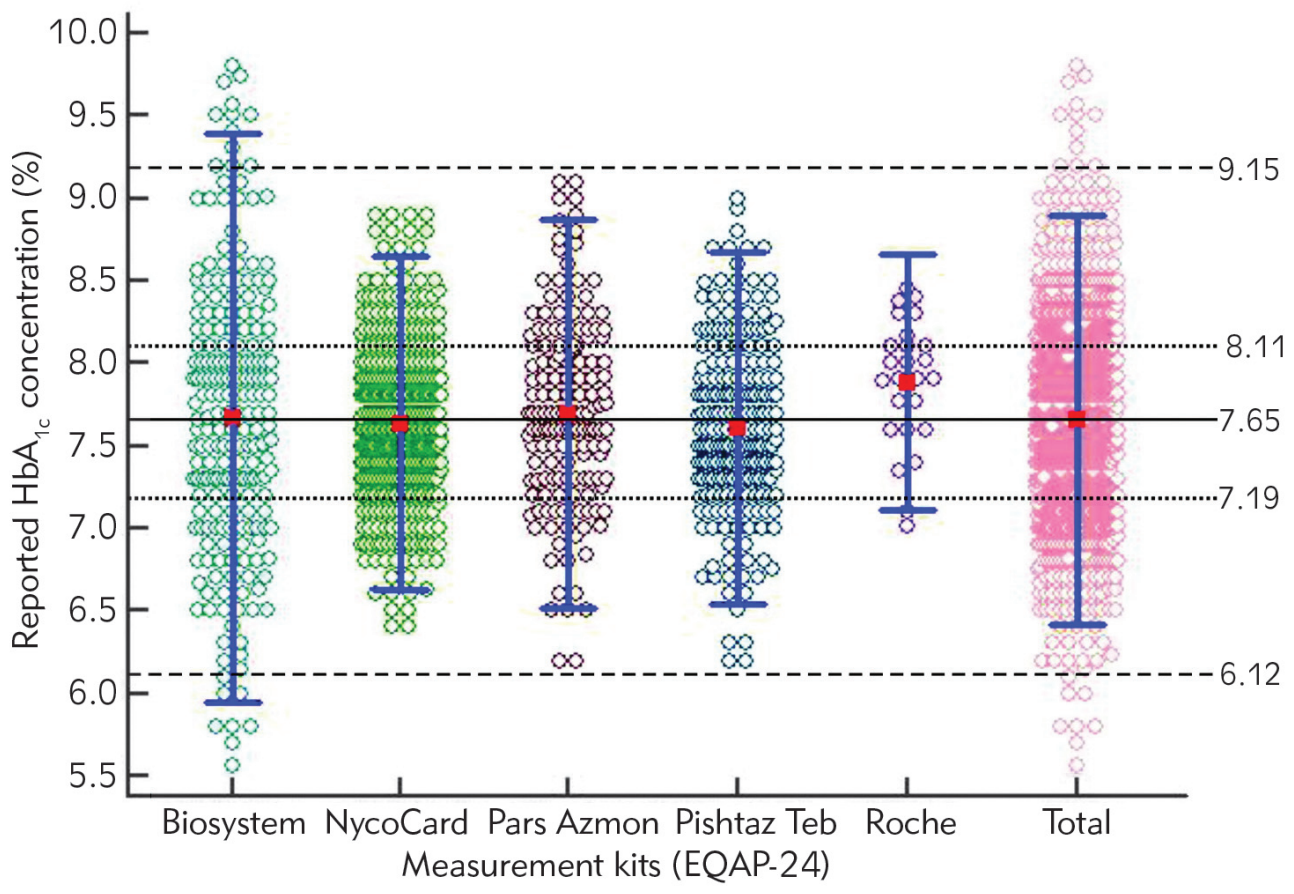

Figure 2 Performance during EQAP-24. Error bars represent \pm 2 SD interval from the means (filled squares). The continuous horizontal line represents the total mean. Dotted and dashed horizontal lines show the allowable interval for total allowable errors of $6 \%$ and 20 , respectively.

which were less than the allowable $\mathrm{CV} \%$ of $1.5 \%$. So, the hemogeneity of the vials containing whole blood samples was confirmed. In the case of stability, the results of stored vials at $4{ }^{\circ} \mathrm{C}$ by the end of the program were $8.20 \%$ in EQAP-23 and 7.95 in EQAP-24, which were in the $6 \%$ acceptable limit of related homogeneity target values, 7.88 in EQAP-23 and 7.70 in EQAP-24, respectively. The results of Mean (target value), SD, CV, TAE, bias, method quality (sigma level with TEa of $6 \%$ and $20 \%$ ) of each peer group and also target value, SD, and CV of total group for participating laboratories using the desired commercial methods in EQAP-23 and EQAP-24, have been shown in Table I. According to CAP allowable bias\% of absolute $0.3 \%$, all mean methods results were within the acceptable range in both EQAP-23 and EQAP-24.

As shown in Table II, when TEa of $\pm 20 \%$ was used to evaluate $\mathrm{HbA}_{1 \mathrm{c}}$ method performance, about $97 \%$ and $98 \%$ of participant laboratories had acceptable performance during EQAP-23 and EQAP-24, respectively. But when this evaluation was performed according to TEa of $\pm 6 \%$ pass rates decreased significantly to $62 \%$ and $60 \%$, respectively.

Data related to $\mathrm{HbA}_{1 \mathrm{c}}$ methods and laboratory performance from EQAP-23 and EQAP-24 are demonstrated as multiple variable graphs in Figures 1 and 2 , respectively. In these graphs, positions of dif- ferent method means in respect to total mean, distribution of data around related means, error bars representing \pm 2 SD interval, and allowable intervals for TEa of $6 \%$ and $20 \%$ are shown.

\section{Discussion}

Reliability of methods for measurements of blood $\mathrm{HbA}_{1 \mathrm{c}}$ has been studied extensively throughout the world (19-24). This reliability for methods which are commonly used in Iran has also been studied previously (12). This study and the present study have three important differences in relation to the other studies. First, in the other studies one method, usually an HPLC method, was chosen as a reference or comparative method and other methods, as test methods, were compared with that one. In this study, we had no access to a reference or comparative method which has no analytical error and whose results could be reliable for comparing the results of other methods. To resolve this problem, commutable fresh patient blood specimens are used instead of noncommutable commercial quality materials and means of all groups are used as target values. It seems this approach is a better approach to obtain results with the least error. Second, in the most of other studies, methods were grouped according to principles of $\mathrm{HbA}_{1 \mathrm{c}}$ separation, including ion-exchange chromatography, affinity chromatography, immunoturbidimetry, enzymatic, etc. But, in this 
study, methods were grouped according to commercial methods. In spite of using similar principles, products of different manufacturers may have different performance. For example, in this study, both Roche and Pars Azmon kits used immunoturbidimetric methods, but their performance (bias\%, CV\%, and sigma level) was completely different. Third, in this study, we used a formulation to account the effect of the number of repeating measurements in reducing random error and calculating analytical bias properly. This may be the first time that such a formula has been used in the calculation of bias, TAE, and mTEa.

Allowable total error (TEa) is a parameter used to define acceptable analytical performance which defines the amount of error that can be tolerated without invalidating the medical usefulness of the analytical result. If TAE is less than TEa, then the performance of the test is considered acceptable. If this error is larger than the TEa, corrections should be made to reduce the analytical error or the method should be replaced. This process ensures that laboratory test results give accurate information to physicians to manage their patients effectively (25).

According to the Diabetes Control and Complications Trial (DCCT), $\mathrm{HbA}_{1 \mathrm{c}}$ results $<7.0 \%$ show good glycemic control and results $>8.0 \%$ show poor glycemic control. In order to properly classify a patient with an $\mathrm{HbA}_{1 \mathrm{c}}$ value of $7.5 \%$, total analytical error of measuring should be maximally $\pm 0.5 \%$ (as the absolute value of $\mathrm{HbA}_{1 \mathrm{c}}$ ), which equals relative total error of $\pm 6.7 \%$. If TAE is greater, a patient with an $\mathrm{HbA}_{1 \mathrm{c}}$ value of $7.5 \%$ will be incorrectly classified in good or poor glycemic control groups, which is obviously not acceptable (3).

Results of our study show that using CCV\% $=10 \%$ and $\mathrm{SDI}>2$ for evaluating $\mathrm{HbA}_{1 \mathrm{c}}$ method performance (equals to TEa of 20\%) is not proper according to clinical needs and leads to misclassifying about $37 \%$ of laboratories as acceptable. So, if we want the $\mathrm{HbA}_{1 \mathrm{c}}$ results to be useful for managing diabetic patients, it is necessary to use TEa $=6 \%$ which is now suggested by NGSP and used in CAP surveys for evaluating laboratory performance in measuring $\mathrm{HbA}_{1 \mathrm{c}}$ (26).

As shown in Table I, when we used TEa by 6\%, quality (sigma metrics) of all the methods were unacceptable (sigma level less than 2.0). But, when we used TEa by $20 \%$, this quality was acceptable, except for Biosystem. Means of each method bias, imprecision, and quality were determined according to TEa of $6 \%$ and $20 \%$. According to these means, Biosystem had the least bias and the greatest imprecision. In contrast, Roche had the least imprecision and the greatest bias. Mean sigma quality showed that according to TEa of $6 \%$, all methods had poor performance (sigma level less than 1.0), but with TEa of $20 \%$, all methods had acceptable performance (sigma level more than 2.0), except for Biosystem.
In 2015, Huysal K. and Budak Y. (8) reported the results of their study on MQ-2000 PT HbA $1 c$ analyzer which uses HPLC and separates $\mathrm{HbA}_{1 \mathrm{c}}$ by cation exchange. They used TEa of $10 \%$, which is recommended by the Clinical Laboratory Improvement Amendments (CLIA) regulations $(8,9)$, and calculated the sigma level for assessment of quality of this analytical performance (9). They obtained a sigma level of less than 1.5 and showed that the analytical quality of the MQ-2000 PT HbA 1 c analyzer was not appropriate when evaluated on the sigma scale (9). In comparison to using TEa about $6 \%$, when we use TEa by $10 \%$, method performance improves and method quality sigma value increases. But the meaning of this quality improvement is not the improvement in the clinical usefulness of $\mathrm{HbA}_{1 \mathrm{c}}$ results. Thus, in order to increase clinical usefulness of $\mathrm{HbA}_{1 \mathrm{c}}$ results, we should decrease TAE, but not increase TEa.

In 2007, the CAP used wide acceptance limits of $\pm 15 \%$ for evaluating the performance of laboratories measuring $\mathrm{HbA}_{1 \mathrm{c}}$. In 2008, the CAP narrowed this limit to $\pm 12 \%$, and then in 2009 to $\pm 10 \%$, in 2010 to $\pm 8 \%$, in 2011 to $\pm 7 \%$, and finally in 2013 to $\pm 6 \%$ (18). If we use the sigma value to evaluate method performance in the CAP survey, surprisingly, the method performance would be too low. In this survey, acceptable limit (TEa), bias and CV are $\pm 6 \%$, $0.3 \%$, and $4 \%$, respectively. Here, limit bias is given according to the absolute amount of $\mathrm{HbA}_{1 \mathrm{c}}$. With a target value of $7 \%$, bias $\%$ will be $4.3 \%$. So, a method with maximum acceptable bias $\%$ and $\mathrm{CV} \%$ could have a very low sigma of 0.4 ! In 2016, in the GH5-B survey, for example, Roche Cobas Integra 400 had a bias $\%$ and $\mathrm{CV} \%$ of about $2.3 \%$ and $3.6 \%$, respectively. In other words, this method was 1.0 sigma.

In 2015, Mosca et al. sent two fresh blood samples to 206 Italian laboratories asking for the determination of their $\mathrm{HbA}_{1 \mathrm{c}}$ concentration (27). Here, 193 laboratories using analytical systems from five manufacturers (Bio-Rad Laboratories, A. Menarini Diagnostics, Roche Diagnostics, Sebia and Tosoh) obtained a global variety of $5.3 \%$ (in terms of $\mathrm{CV}$ ) and of $3.8 \%$ at an $\mathrm{HbA}_{1 \mathrm{c}}$ value of $5.6 \%$ (sample 1) and $7.8 \%$ (sample 2), respectively. With a TEa of $6.0 \%$, pass rates were $70 \%$ and $77 \%$ of samples 1 and 2 , respectively. All methods had a mean bias of $\leq 2.8 \%$ with respect to the target values, with the exception of Tosoh (bias of +6.1 and $+5.8 \%$, for samples 1 and 2, respectively) (27). Our results are comparable to theirs. Our bias is somewhat better and our inter-laboratory $\mathrm{CVs} \%$ and pass rates are worse than theirs.

\section{Conclusion}

According to our study and comparison with the results of other related studies in different countries, we can conclude that (1) the calculated sigma and 
$\mathrm{HbA}_{1 \mathrm{c}}$ performance methods in Iran are comparable to the other countries and still there is a need to improve these method performances all over the world (2). Our laboratory pass rate is low and interlaboratory CV\% is high and these must be improved by using closed and NGSP-certified methods. And we need to gradually tighten the TEa from the improper $\pm 20 \%$ to proper $\pm 6 \%$ and the Iranian clinical laboratories that have not achieved acceptable results must improve their performance methods gradually, or

\section{References}

1. Kim SR, Lee Y-h, Lee S-G, Lee SH, Kang ES, Cha B-S, et al. Morning spot urine glucose-to-creatinine ratios predict overnight urinary glucose excretion in patients with type 2 diabetes. Ann Lab Med 2017; 37: 9-17.

2. Weykamp C. HbA1c: a review of analytical and clinical aspects. Ann Lab Med 2013; 33: 393-400.

3. Braga F, Panteghini M. Standardization and analytical goals for glycated hemoglobin measurement. Clin Chem Lab Med 2013; 51: 1719-26.

4. Lumsden JH. Laboratory test method validation. Revu Med Vet 2000; 151: 623-30.

5. Little RR, Rohlfing CL. $\mathrm{HbA}_{1 \mathrm{c}}$ standardization: background, progress and current issues. Labmedicine 2015; 40: 368-73.

6. Collinson P. Laboratory medicine is faced with the evolution of medical practice. J Med Biochem 2017; 36: 211-5.

7. McPherson RA, Pincus MR. Henry's Clinical Diagnosis and Management by Laboratory Methods E-Book: Elsevier Health Sciences; 2017.

8. Huysal K, Budak YU. Application of sigma metrics for the assessment of quality assurance using the MQ2000 PT $\mathrm{HbA}_{1 \mathrm{c}}$ analyzer. Biochemica Medica 2015; 25: 416-20.

9. Westgard JO, Westgard SA. The quality of laboratory testing today: an assessment of $\sigma$ metrics for analytic quality using performance data from proficiency testing surveys and the CLIA criteria for acceptable performance. Am J Clin Pathol 2006; 125: 343-54.

10. Mohammadi R, Norozi V. HbA $1 c$ External Quality Assessment: Commutable vs Noncommutable Samples. Biomed \& Pharmaco J 2016; 9: 163-8.

11. Deom A, El Aouad R, Heuck CC, Kumari S, Lewis SM, Uldall $A$, et al. Requirements and guidance for external quality assessment schemes for health laboratories. 1999.

12. Mohammadi R, Norozi V. $\mathrm{HbA}_{1 c}$ Measurement: Comparison of Results of Five Commonly Used Kits in Iran. Biomed \& Pharmaco J 2016; 9: 125-31.

13. Hill P, Uldall A, Wilding P. Fundamentals for external quality assessment (EQA). Guidelines on improving analytical quality by establishing and managing EQA replace their methods with an acceptable $\mathrm{HbA}_{1 \mathrm{c}}$ measuring method (3).

Acknowledgments. This work was supported by Iran External Quality Assessment Program (EQAP).

\section{Conflict of interest statement}

The authors stated that they have no conflicts of interest regarding the publication of this article.

schemes Examples from basic clinical chemistry using limited resources IFCC. 1996.

14. Burtis CA, Ashwood ER, Bruns DE. Tietz textbook of clinical chemistry and molecular diagnostics-e-book: Elsevier Health Sciences; 2012. 194-5 p.

15. McGuinness C, Seccombe DW, Frohlich JJ, Ehnholm C, Sundvall J, Steiner G, et al. Laboratory standardization of a large international clinical trial: the DAIS experience. Clin Biochem 2000; 33: 15-24.

16. Theodorsson E. Quality assurance in clinical chemistry: a touch of statistics and a lot of common sense. J Med Biochem 2016; 35; 150-12.

17. Mullins E. Statistics for the quality control chemistry laboratory: Royal Soci Chem; 2007.

18. Data. CoAPCS. www.ngsp.org/pong/indexhtml (www. ngsp.org).

19. Khan MAH, Rabeya MR, Saiedullah M. Measurements of $\mathrm{HbA}_{1 c}$ by High Performance Liquid Chromatography in D-10 analyzer and Immunological Method by Beckman Coulter AU480 System: A Comparative Study. J Enam Med Col 2012; 2: 62-6.

20. Ozcelik F, Yiginer O, Serdar MA, Kurt I, Oztosun M, Arslan $\mathrm{E}$, et al. Comparison of three methods for measurement of $\mathrm{HbA}_{1 \mathrm{c}}$. Turk J Biochem-Turk Biyokimya Dergisi 2010; 35: 344-9.

21. Sudhakar B, Reddy AS, Fallerio J. Comparison of three methods for measurement of blood $\mathrm{HbA}_{1 \mathrm{c}}$ as to reliability. Int J Bioass 2014; 3: 3000-4.

22. Lippi G, Cadamuro J. Novel opportunities for improving the quality of preanalytical phase. A glimpse to the future? J Med Biochem 2017: 36: 293-300.

23. Yasmeen F, Mumtaz A, Adhami S, Qureshi S. Comparison of cation exchange HPLC and Immunoturbidimetric method for determination of $\mathrm{HbA}_{1 \mathrm{c}}$. Biomed 2011; 27:161-5.

24. Zin RMWM, Kamil ZIA, Soh TRT, Embong M, Mohamud WNW. Haemoglobin $A_{1 c}$ : comparing performance of two point of care devices with laboratory analyser. BMC res notes 2013; 6(1): 540.

25. Bishop ML, Fody EP, Schoeff LE. Clinical chemistry: principles, techniques, and correlations. $6^{\text {th }}$ ed: Lippincott Williams \& Wilkins; 2010. 
26. Weykamp CW, Mosca A, Gillery P, Panteghini M. The analytical goals for hemoglobin A1c measurement in IFCC units and National Glycohemoglobin Standardization Program units are different. Clin Chem 2011; 57(8): 1204-6.
27. Mosca A, Paleari R, Carobene A, Weykamp C, Ceriotti F. Performance of glycated hemoglobin (HbA 1c) methods evaluated with EQAS studies using fresh blood samples: Still space for improvements. Clinica Chimica Acta 2015; 451: 305-9.

Received: September 24, 2017

Accepted: December 25, 2017 